\title{
Breaking the Ethnic Barrier in Mark 7:24-30: Implication for the Ghanaian Context
}

\author{
Alice Matilda Nsiah' \\ 1 Department of Religion and Human Values, University of Cape Coast, Ghana.
}

\begin{abstract}
The study aims at interpreting Mark 7:24-30 to establish whether Jesus was initially reluctant in helping a needy woman because she was non-Jewish, or the author was establishing the gradual breaking of ethnic and all other barriers to redefine the scope of Jesus' ministry. The study uses African Biblical Hermeneutic theory of Gerald West that allows a dialogue between the text and the African context. It argues that the text may be interpreted as a covenant renewal discourse aimed at including Gentiles into the covenant family. The study concludes that unproductive ethnic and religious barriers may be broken for the common good of God's family. It-recommends the importance of mutual respect in dialogue in the face of diversities of opinions and perspectives.
\end{abstract}

Keywords: Ethnicity, Barriers, Covenant, Discourse.

(C) 2021 The Author(s). Published and Maintained by Noyam Publishers.

This is an open access article under the CCBY license (http://creativecommons.org/licenses/by/4.0/).

\section{INTRODUCTION}

Ethnicity defies any singular definition since it cuts across many fields of discipline. It is generally understood as referring to a group due to its collective cultural characteristics. The identity of the group is explained on the presumption that its members descended from one ancestor. The word comes from the Greek-ethnos which literally means 'nation' or 'people' or 'ethnic groups within a nation'. Williams argues that an ethnic group may also refer to people of a particular religion with certain distinctive characteristics. ${ }^{1}$ Isajiw defines ethnicity as a phenomenon that is individually and collectively experienced. ${ }^{2} \mathrm{He}$ also describes-ethnicity as having objective and subjective dimensions. According to him, while the objective dimension establishes a common ancestor who was the focus of cultural transmission and identity formation of the group, the subjective dimension manifests itself in attitudes, values and preconceptions of members in the context and process of communication. ${ }^{3}$ It is this subjective dimension that creates ethnic boundaries that may include or exclude others. ${ }^{4}$ Berreman explains that although particular distinctive characteristics are assigned to an ethnic group, individual members of the group acquire those attributes by learning and through socialization

1 R.M. Williams. What is Ethnic Ethnicity in International Encyclopaedia of The Social and Behavioral Sciences. Science Direct, (2001): 4806-4810.

2 Wsevolod W. Isajiw, Definition and Dimensions of Ethnicity: A Theoretical Framework in Challenges of Measurement on Ethnic World: Science, politics and reality: Proceedings of the Joint Canada-United State Conference on Measurement of Ethnicity April 1992, Statistics Canada and U.S. Bureau of Census, eds. (Washington D.C.: Government Printing Office: 40727, 1993).

3 Isajiw, Definition and dimensions of Ethnicity, 412.

4 Isajiw, Definition and dimensions of Ethnicity, 413-6. 
and not something intrinsic or in-born. ${ }^{5}$ Sarpong clarifies that a person does not choose his/her parents, but once she/he is born, all other attributes are acquired. He explains further that with time, a person may choose to drop one attribute in favour of another that may be more beneficial. ${ }^{6}$ Hence, putting emphasis on an element of an ethnic group is a choice of an individual or community.

Just argues that the term hellenis in the Bible often refers to all other nations as a collective body except the Jewish nation. ${ }^{7}$ He explains this understanding as based on the fact that during biblical times, most nations had their own religion and their own gods and thus the concept of ethnicity was understood in terms of nation-states, in terms of ethnic groups and in terms of religious groups. ${ }^{8}$ He adds further that when the term is used for all other nations in the Bible, it is understood as Gentiles. In this connection, the term Jews in the Bible refers to an ethnic group as well as a religious group, which is different from the term Jews today, since many religious Jews today come from different ethnic groups and some ethnic Jews do not practice Jewish religion. ${ }^{9}$ In this study, the word ethnicity is understood in its biblical sense as well as a modern understanding of subgroups within a nation whose members may not share the same religion. Ethnicity, therefore, is any ideologically created group that provides a social, religious and cultural identity as well as security. It is a phenomenon that may involve both positive and negative orientations towards members of one's own ethnic group and members of other ethnic groups respectively. ${ }^{10}$ This study focuses on how Jesus handled ethnic and other boundary issues in his ministry in Mark 7:24-30.

\section{METHODOLOGY}

This article uses the African Biblical Hermeneutic theory as proposed by Gerald West who also followed the Tri-polar exegetical Model of Jonathan Draper. According to West, African Biblical Hermeneutics consists of three poles: the text, the context, and appropriation. ${ }^{11}$ With regard to the text, West suggests the need to establish a clearly identifiable unit or pericope that must be read with the theory of distantiation. This theory states that the meaning of a text is irrespective of the author's intended meaning. ${ }^{12}$ With regard to context and appropriation, West discusses that since it is the reader who makes dialogue between the text and the context possible, it is important that a particular orientation of Africa be adapted in the reading process. This is to ensure that interpretation of a text is not an end in itself but a means to a transformation that is personal, communal and contextual. He offers samples of such orientations as Liberation Hermeneutics that focus on the cultural and emancipatory well-being of Africa since the Bible is considered to contain both liberative and oppressive elements. This allows the text to serve as a critique of the African context and vice versa. Since the text contains elements of healing across barriers, the article uses liberation ideo-theological orientations in reading the text.

\footnotetext{
5 G.D. Berreman. Inequality: Comparative Aspects in Ethnicity in Internal Encyclopedia of the Social and Behavioural Sciences. Science Direct, 2001, 7377-7382. Retrieved from: https://doi.org/10.1016/BO-08-043076-7/00893-7.

6 Peter Sarpong. Ghana in Retrospect: Some Aspects of Ghanaian Culture. (Tema: Ghana Publishing Corporation, 1974), viii.

7 Felix Just, Ethnic / National / Religious Groups in Biblical Times. Catholic Resources for Bible, Liturgy, Arts and Theology, 2019, http:/catholic-resource.org/bible. Accessed on $3^{\text {rd }}$ May 2019.

8 Just, Ethnic / National / Religious Groups in Biblical Times.

9 Just, Ethnic / National / Religious Groups in Biblical Times.

${ }^{10}$ Robert M. Price. "Patterns of Ethnicity in Ghana: A Research Note, Journal of Modern African Studies, Vol. 11, No. 3 (September, 1973), 470-475.

11 Gerald West. 'Biblical Hermeneutics in Africa'.In A Reader in African Theology. John A. Parratt (Ed.). (London: SPCK 1987).

12 Paul Ricoeur Interpretation Theory: Discourse and Surplus of Meaning (Fort Worth, Texas: The Texas Christian University Press, 1976), 29ff.
} 


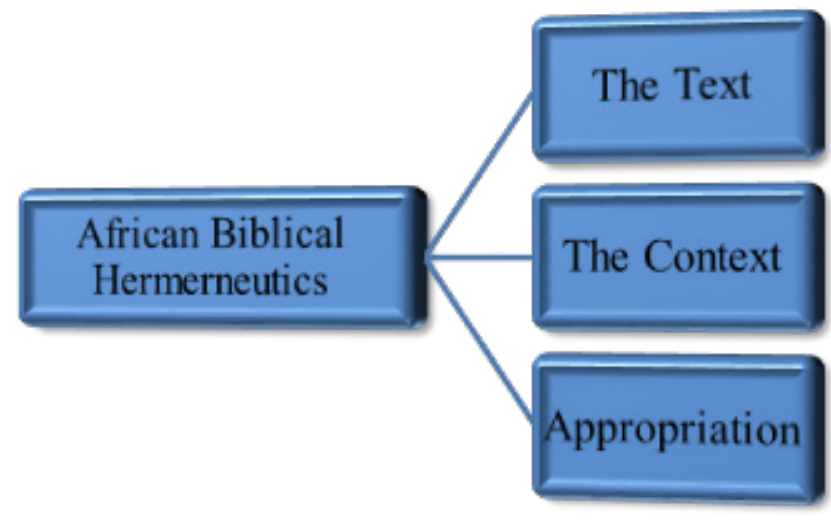

Figure 1 African Biblical Hermeneutic Theory. Source: Nsiah, 2018

Figure 1 is a graphic depiction of African Biblical Hermeneutic theory. The three poles emanating from the theory are the suggested processes by which a reader may engage a biblical text and appropriate the outcome in a particular context for the necessary transformation. The process does not follow a rigid compartment. One may begin with the text and move to the context and vice versa.

\section{FIRST POLE OF THE WORK: THE TEXT}

\section{Exegesis of Mark 7:24-30}

Mark 7:24-30 has a parallel in Matthew 15:21-28 and echoes Elijah's story (1King 17:8-24) where the only son of a widow died and was raised by the prophet in Zarephath in a Sidonian territory. This story is also similar to the initial experience of Peter before ministering to the household of Cornelius where he was instructed not to call unclean what God had cleansed. ${ }^{13}$ This passage is a unit of its own because it has a clearly identifiable beginning, middle and closing. The story also stays in harmony with the preceding pericopes (6:35-7:30) and the ones that follow it. Mark 7:24-30 is seen as a natural sequence of 7:1-23. With the exception of 6:5356 , the other subunits are linked together by the theme of bread $(6: 41,52 ; 7: 2,27)$. Lane argues that Mark intentionally placed this incident in a foreign region and he did so immediately after a discussion on clean and unclean foods. The purpose of this was to provide a concrete example of how Jesus' teaching goes against the general expectations. It provides a new twist to traditional truth to surprise his audience and attract their attention. ${ }^{14}$ The episode appears to contain formal characteristics of both a miracle story and a controversy. The initial controversial dialogue that takes place before the miracle makes this story unique and a very interesting one. Since dietary laws were a very important purity requirement, this purity discourse must have been very important to the community of Mark and provides a natural precedent to breaking boundaries. ${ }^{15}$ For the sake of clarity, the passage is divided into three parts: introduction (24), the body (25-29) and closing (30). The discussion will follow this order.

\section{Introductory section (Verse 24: opening section)}

The episode begins with ekeithen de anastas apelthēn horia tyros (from there he got up / arose and went away to the region of Tyre). The movement to a new area signals the beginning of a subunit. What makes this particular one interesting is the fact that it marks the beginning of Jesus' travel to a foreign region in Mark. The region around Tyre is an ancient Phoenician city and shares borders with Galilee and is in the northwest of Capernaum. Sidon is a few miles north of Tyre. It is possible that many Jews live in this area. What is going to happen in Tyre becomes clearer in the next half of the verse.

\footnotetext{
13 William L. Lane, The Gospel According to Mark, The English Text with Introduction, Exposition, and Notes. (Grand Rapids, Michigan: William B. Eerdmans Publishing Company 1974), 259.

14 Lane, The Gospel According to Mark, 259.

${ }^{15}$ Christopher Alt 'The Dynamic of Humility and Wisdom: The Syrophoenician Woman and Jesus in Mark 7:24-30' Lumen Et Vita 2(1), (2012).
} 
Eiselthōn oikian oudena èthelen gnōnai ouk èdynēthè lathein' (he entered a house and wished to remain unrecognized, but he could not escape notice). It is told that Jesus entered a house to avoid attracting the attention of the public (9:30-31). The house is to provide a little confinement. Sometimes, healing or teaching also takes place in a house (Mk. 2:1ff) and suggests that Mark's community at this time was a house church. ${ }^{16}$ The house also connotes the idea that those who come to see Jesus are those who had heard about his deeds and had confidence in him $(2: 1-5,3: 20 ; 7: 24-30) .{ }^{17}$ This house must have been a Jewish home so that Jesus will not have purity problems. Perkins suggests that the popularity of Jesus has spread and the demand for his attention has become so persistent in the Galilean regions that it was becoming difficult for him to get a private time to be with his disciples $(6: 31,53-56)$ and so he sought for privacy in foreign regions to rest and to teach his disciples. ${ }^{18}$ Jesus did not wish to be noticed but it seemed difficult for him to live a quiet life during his international travels because he had already had contact with a delegation from Tyre and Sidon (3:8) and was famous for his power to heal and cast out demons. Being sought after against his will may also be a technique Mark uses to heighten Jesus' power over earthly forces and the theology of the messianic secret. ${ }^{19}$ The fact that Jesus is sought after even in Gentile territories heightened his fame among Gentiles. Thus, this introduction is to arouse the expectation of readers and prepare them for the main encounter that is to be discussed in the next section.

\section{The Body of the Text (Verses 25-29)}

This section is also further divided into two sections: the background information (25-26) and the climax of the story (27-29). The discussion will follow this order.

\section{The background to the encounter (25-26)}

All'euthys akousasa gyne peri autou (immediately a woman heard about him). The word 'immediately' or 'at once', 'straight away' (euthys) betrays the fact that Mark is always fond of demonstrating the urgency in the movement and activities of Jesus $(1: 21,30,6: 25)$. It also shows the alarming rate at which his fame spread in a Gentile territory so that a woman heard (akousasa) of him. The little daughter (thygatrion) of this woman had pneuma akatharton which literally means an unclean/evil spirit (1:23,26, 3:11, 30, 5:8, 6:7, 9:25). The spirit is unclean in the sense that it is opposed to God who is pure and holy and sometimes Mark calls these evil spirits 'demons'. ${ }^{20}$

Mark narrates that the woman prosepesen from prospiptō which means that she prostrated herself at the feet (podas) of Jesus. This demonstrates her humility in approaching Jesus. To fall down at his feet is to show reverence and to worship him, probably acknowledging Jesus as Lord. It is interesting to note that Mark did not talk about the Apostles although they were with him (7:2,5, 17 and 8:1) even in his private moments to further explain things to them. Matthew supplies the information that the disciples were with Jesus. Alt rather suggests that Jesus is curiously alone without his disciples. ${ }^{21}$ Perhaps Mark wanted to stress the quality time Jesus spent with this Gentile woman.

In verse 26, the non-Jewish character of this woman was heightened so much that it became her name. She is described as Hellenis Syrophoinikissa which literally means a Greek from Phoenicia in the province of Syria. This indicates that the woman was born a Gentile and culturally Hellenized. There is no indication that she is a proselyte or follows the Jewish religion. As a Hellenized Greek, she must have followed other religions. It is this woman with such a background, who begged Jesus to ekbale (drive out / expel) the demon from her daughter. There is no indication that this unnamed woman had had previous contact with Jesus but heard of his ability to heal and cast out demons. ${ }^{22}$ There is also no mention of her husband or the father of the girl. The background of the woman may be graphically portrayed as follows:

\footnotetext{
${ }^{16}$ John R. Donahue and Daniel J. Harrington, The Gospel of Mark. (Collegeville, Minnesota: The Liturgical Press, 2002).

17 Lane, The Gospel According to Mark, 260.

18 Pheme Perkins. 'The Gospel of Mark: Introduction, Commentary, and Reflections' in The New Interpreter's Bible Vol. VIII (Nashville: Abindon Press, 1995), 673-674.

19 Donahue and Harrington, The Gospel of Mark, 232-233.

20 Donahue and Harrington, The Gospel of Mark, 233.

21 Alt, The Dynamic of Humility and Wisdom.

${ }^{22}$ Lane, The Gospel According to Mark, 260.
} 


\begin{tabular}{|l|l|}
\hline The Woman & Background \\
\hline Gender & Female though not poor but in need of a favour from a powerful man. \\
\hline Religion and culture & Pagan / non-Jewish / Gentile / Hellenized \\
In terms of purity & She is described as dog or unclean to be ministered to \\
\hline Nationality / ethnicity & Syrophoenician \\
\hline Historically & Tyre has a history of conflict with the Israelites \\
\hline Socially & $\begin{array}{l}\text { She has a demon-possessed daughter, probably without a father, a woman is } \\
\text { not to speak to a rabbi in public (John 4:27). She may be without a husband } \\
\text { or elderly son. }\end{array}$ \\
\hline Economically & $\begin{array}{l}\text { The woman is a lady with a class (this sets her aside from most poor people } \\
\text { that approach Jesus.) }\end{array}$ \\
\hline
\end{tabular}

Table 1 Background of the woman. Source: Nsiah, 2019

Table 1 shows that the woman was an outsider by all standards. She was just the opposite of what Jesus was and she met Jesus at the wrong time when he did not want to be noticed. The background is set for the encounter between the woman and Jesus. Up to this point, the text has followed a typical miracle story. The next section discusses how Jesus responded to this request.

\section{The Climax of the Encounter (Verses 27-29)}

The response of Jesus is uncommonly harsh and strange because no one has been treated this way before Jesus. ${ }^{23}$ Kai elegen aute: aphes prōton chortasthènai ta tekna (And he said to her, allow the children to be satisfied first) ou kalon estin labein arton teknōn kynariois balein (for it is not good to take the bread of the children and throw it to little dogs). The woman did not ask for food but healing, so why is Jesus talking about bread which appears to be unconnected to the issue at stake? ${ }^{24}$ Jesus appears to be speaking with metaphors and before these metaphors are understood, it is important to understand who are considered children and who are dogs. The people of Israel are addressed as children reminiscent of a concept in the Old Testament (Deut 32:20; Ps 82:6; Is 1:2, 63:8; Hos 11:1). Israel is collectively called the 'son of God' in a covenant context. The Israelites became the children of God and God became their father. This is clearly affirmed in Matthew (5:24). Again, Kynarion from kyon were used as watchdogs that lived on the street as scavengers (1Kings 14:11) and so were regarded as unclean. Consequently, such a term is used as a reproach (1Sam 24:14; 2 Sam 3:8, 9:8, 16:9). Paul calls Heretics dogs (Phil 3:2) and Gentiles are called dogs (Matt 15:26; Rev 22:15) in the sense that they are unclean. With the use of the term "children" and "dogs", a comparison is thus created between Jews and Gentiles in terms of their importance in the missionary activities of Jesus. Furthermore, the description of gentiles as unclean dogs links this unit to the preceding one where clean and unclean food is discussed. It is the unclean nature of dogs that made the situation of Lazarus in eating the scraps for dogs and dogs licking his wounds very degrading. Thus, Jesus appears ethnocentric in all of its dimensions. But here little dogs refer to house dogs/ pets in contrast to wild dogs. What does Jesus mean?

The issue of 'First' which reveals a sequential order of activity echoes the idea that the people of Israel must be fed first. This gives a glimmer of hope that there might be a second feeding. The notion of 'First' again reflects a Pauline thought that the good news was first preached to the Jews and then progressively to the Gentiles (Rom 1:16, 2:9f; Acts 3:26, 13:46). ${ }^{25}$ Paul was influenced by the covenant promise to Abraham (Gen 12:3) that gives a special privilege to Jews as against non-Jews in terms of salvation.

Gundry suggests this as an allusion to the two feeding miracles in Mark (6:30-44 and 8:1-10) to the Jews and Gentiles respectively. This metaphorical way of feeding the children links this passage to the larger pericope and the two feeding incidents. Jesus made it clear that his ministry is primarily restricted to Israel. Therefore, Jesus re-echoes the covenant promise to Abraham metaphorically. The metaphoric

\footnotetext{
23 Robert H. Gundry Mark: A Commentary on His Apology for the Cross. (Grand Rapids, Michigan: William B. Eerdmans

Publishing Company, 1993), 372; Donahue and Harrington, The Gospel of Mark 233.

24 Donahue and Harrington, The Gospel of Mark, 232.

25 Donahue and Harrington, The Gospel of Mark, 233.
} 
statement presumes a very high degree of theological sophistication and readers are not sure whether the woman possesses such a background for understanding Jesus. ${ }^{26}$

In verse 28, the natural response expected of the woman is to be disappointed, angry, or sad at such insult and walk away. Yet, this is where the teachings of Jesus take a twist to surprise the expectation of his audience. Instead of walking away, the desperate woman reverently addressed Jesus as Lord, and compared herself and all Gentiles to house dogs that were usually present at meals in a Hellenistic home. Thus, she contextualizes the metaphor of Jesus and adapts it to her own Hellenistic context to elicit the right of children to share their food with pet dogs. In this way, she was able to outwit Jesus with her argument. Pet dogs enjoy the crumbs of children that drop from the table. This indicates that the woman understood that worship of God started with Abraham and that at the time of the covenant, other nations did not know God. The worship of God will come to other nations through the descendants of Abraham. Gentiles will be blessed when they have come to know God and this is the point of the story and the effect of the dialogue between Jesus and the woman. The text shows that the presence of Jesus marks the appointed time promised in the covenant promises.

Verse 29 begins with kai eipen autē, dia touton ton logon hypage exelēlythen ek tēs thygatros daimonion (and he said to her, 'go, the demon had gone out of your daughter'). Jesus acknowledged the greatness of the woman and finally healed the unnamed daughter based on the words of the woman. Her words may be said to be her confession of faith, which is rightly pointed out by Matthew (15:28). This is one of the few healing miracles from a distance, without physical contact and this is to heighten the power of Jesus. Jesus has broken the ethnic and religious barriers between Jews and gentiles and by implication for all people.

The body of the text is very revealing. It builds the encounter between Jesus and the gentile woman gradually until it reaches its climax in the healing of the girl and the dismissal of the woman. The next section discusses how the subunit closes.

\section{Closing Section (30)}

In verse 30, the woman went home and found her daughter lying in a couch (klinēn), which reminds one of the healing of the paralytic (2:1-12) who was lying on a krabbatos (mat) which was perhaps for the poor and simple, while a couch denotes some amount of the wealth of the woman (kings 4:32). ${ }^{27}$ The daughter was well to confirm the miracle, which indicates that the demon had gone. Gentiles may now enjoy part of the blessings promised to Abraham.

A number of things to be noted from the readings:

- That there is Jewish priority in Jesus' missionary activities and this is in fulfilment of the covenant promises to Abraham.

- The above theology is also Pauline.

- The whole event may therefore be regarded as a covenant renewal episode.

- Gentiles who confess their faith are included in the covenant community of God.

- In this case, the words of the woman form her confession of faith.

- The effect of the renewal is transformation on the part of Jesus to redefine the boundary of his ministry to show the place of Gentiles in his missionary activities.

- The woman also experiences liberation, healing, and salvation for herself and her household.

- In effect, Jesus has abolished ethnic, religious, barriers that are not productive and beneficial.

- The text exposes both the positive and negative dimensions of ethnicity.

The encounter of Jesus with the Syrophoenician woman highlights three main dimensions of human relationships individually and communally. They are ethnic, gender and religious. However, in the text, their ethnic and religious nature was highlighted as against gender. Hence, these two areas will be looked at in the context of Ghana in the next section.

\footnotetext{
${ }^{26}$ Lane, The Gospel According to Mark, 262-263.

27 Donahue and Harrington, The Gospel of Mark, 235.
} 


\section{THE SECOND POLE OF THE WORK: THE CONTEXT Introduction}

This section of the work investigates the Ghanaian context with her different levels of divisions in an attempt to provide a conducive atmosphere for dialogue with the selected text. The areas identified are ethnic, religious, gender and political that came out from the analysis of the text.

\section{Ethnic divisions in Ghana}

Ghana like most African countries is a multi-ethnic nation and because of this, it is also multi-lingual, multicultural and multi-religious. The major ethnic groups are the Akan (47.3\%), the Mole Dagbani (16.6\%), the Ewe, $\left(13.9 \% 0\right.$ the Ga Adangbe (7.4\%), the Gurma (5.7\%) and the Guan $(3.7 \%) .{ }^{28}$ Each group may be further divided into subgroups and the subdivisions of each group may share a common origin, cultural heritage, language and/or history. ${ }^{29}$ The biggest ethnic group is the Akan which consists of the Asante, Fante, Bono, Ahafo, Kwahu, Akyem, Akwapim, Nzema, Ahanta and Sefwi. They occupy Ashanti, Bono-Ahafo, ${ }^{30}$ the Central, the Eastern and Western parts of Ghana. These divisions are based on language groups and each language group is referred to as a tribe subgroup. The Mole-Dagbani, the second biggest group, was one of the earliest kingdoms to emerge in present-day Ghana and occupies the Northern part of the country. The Ewes occupy the Eastern, the Ga-Adangbes occupy the Greater Accra and part of the Eastern regions and Guans are spread over the country. ${ }^{31}$

Although there is a rich ethnic diversity that is closely related to geographical and regional divisions in the country, there is no region that is ethnically homogeneous. This is due to the fact that Ghanaians, in general, enjoy free geographical and social migration so much that people of different ethnic groups are scattered all over the country for various purposes. This is confirmed by the 2010 census which indicated that $39.7 \%$ of the population of Greater Accra are Akans.

It is also important to note that before Ghana became a nation, these different ethnic groups were independent states that were fighting for land and supremacy among themselves and some states were vassal to others. Within the Akan group, for example, other tribes were considered to be vassal states to the Asante Kingdom. Asante and Gyimah-Boadi argue that when Kwame Nkrumah separated the then Brong-Ahafo region from the Ashanti region and made it an independent region in 1958, there were persistent squabbles as to whether the Akans in Brong-Ahafo were still vassal state to the Asante kingdom. ${ }^{32}$ Sometimes the different ethnic groups in neighboring regions fight over the ownership of lands and other properties. Such as the Asante and Fanti or Denkyira-or Akyim-These petty litigations were not resolved when these groups were put together as a nation by the British Colonial Masters. In the Northern region for example, the clash between the Konkomba and Bimomba tribes that have lingered on for a long time, has created insecurity, mistrust and lack of development, apart from life and properties that have been destroyed so far. ${ }^{33}$

Ghana may also be said to be divided into two main parts: north and south. The southern part of Ghana appears to relatively enjoy political and economic dominance with many developmental projects including education, health, road network among others, but the northern part is generally considered under-developed and poor. ${ }^{34}$ Consequently, internal migration tends to flow more from north to south for job opportunities and a better life. Awumbila argues that about $60 \%$ of the poorest population in Ghana may be located in the three Northern regions. ${ }^{35}$ She continues that while poverty could be eradicated in the south by 2030, it is expected to continue to affect about $40 \%$ of people in the North. Although different governments have attempted to remedy the situation with different strategies including free education for example, the problem persists. In

${ }_{28} 2010$ Population \& Housing Census: Summary of Final Report. Accra: Ghana Statistical Service. 2012.

${ }_{29}$ Richard Asante \& E. Gyimah-Boadi, Ethnic Structure, Inequality and Governance of the Public Sector in Ghana. Published by United Nations Research Institute for Social Development (UNRISD) 2004,http://unrisd.org/80256B3C005BCCF9/ (httpAuxPages)/8509496C0F316AB1C1256ED900466968.

30 This Region has now been divided into Bono East, Bono and Ahafo regions.

31 Asante and Gyima-Boadi. Ethnic Structure, 8-10.

32 Asante \& Gyimah-Boadi, Ethnic Structure 12-14.

33 Asante \& Gyimah-Boadi, Ethnic Structure, 13-14.

34 Asante \& Gyimah-Boadi, Ethnic Structure, 15-20.

35 Mariama Awumbila, 'How to Close the North South Gap in Ghana (interview at The 2016 Global Forum on Development. (Reported by Andrew Wheeler (2017) retrieved from https//idear4development.org. Accessed on 15 ${ }^{\text {th }}$ February 2020. 
the south, some northerners are, for example, employed to do menial work like truck pushing, head porters (popularly known as Kayaye), rubbish collectors, toilette cleaners, house-helps among others. In performing these duties, people from Northern Ghana acquire certain names in the South that seems to humiliate them. They are called Ntafo which literally means twins or people who move in pairs. Sometimes, northerners are also called pepefo (outspoken, forthright people) and sometimes esremfo (from the Savannah area). However, these terminologies are not bad in themselves, but their persistent use has acquired some insulting connotations as words that discriminate against northerners in the south and denigrate them. ${ }^{36}$ In the same way, southerners are sometimes described as Kwaemufo (people from the forest), nkurasefo (born in a village), mpoanofo (coastal dwellers), or anwonafo (Anlo people from the Volta Region). Although these names may not be bad, the circumstances and their manner of use discriminate and denigrate their referent and expose the negative side of ethnicity. ${ }^{37}$

\section{Religious Situation in Ghana}

Lastly, there are three main religions in the area: The African Traditional Religion (ATR), Christianity and Islam. The 2010 census gives the breakdown as follows: Christian $-71.2 \%$ (Pentecostal/Charismatic $-28.3 \%$, Protestant $-18.4 \%$, Catholic $-13.1 \%$, other $-11.4 \%$ ), Muslim $-17.6 \%$, traditional $-5.2 \%$, other $-0.8 \%$, none $-5.2 \% .{ }^{38}$ Christians have a majority group in the south and Muslims have a majority group in the north and members of ATR are spread through the country. There is a growing competition among the different religious groups in Ghana on two fronts: the first is the media level where Christians, Muslims and ATR adherents use television, radio, audio cassettes, pamphlets and brochures as means of evangelization. ${ }^{39}$ The competition seems to say that the more a type of religion is manifested on social media, the better that religion is as compared to its alternatives. Such competition is a recipe for hostility and makes it difficult to regard others as potential friends. However, it is the competition at the community level that is more worrying. So far, the relationship between Muslims and Christians in Ghana appears to be cordial and collaborative. What sparks frequent violence is the relationship between members of African Traditional religion and Christians over some traditional annual observances and Christian celebrations. This is particularly articulated in the annual one-month ban on drumming and noise-making imposed by the Ga Traditional Council on all people residing within Accra and its environs prior to the celebration of the Homowo festival. According to the $\mathrm{Ga}$ traditional priests, this is a period to leave the gods undisturbed to attend to the farm products to ensure a bumper harvest. Some Christian churches look at this imposition as a way of suppressing the churches and the many foreigners that reside in the Ga traditional area. Some unidentified youth also take it upon themselves to ensure total compliance with the dictates of the ban. On 31 members of the Korle Bu branch of the Lighthouse Chapel during worship and confiscated the church's costly instruments. ${ }^{40}$ Again, on $9^{\text {th }}$ May 1999, members of the Awoshie branch of Victory Bible Church were attacked and some instruments confiscated by angry Ga youth. ${ }^{41}$ Some impasses between the authorities of traditional religion and some members of Christian churches in the capital city of Accra still persist. These are signs of a lack of effort to appreciate and respect the belief systems of others.

Apart from these ethnic and religious divisions in Ghana, there are other barriers between the educated and uneducated, the rich and the poor, the powerful and less powerful, and rural and urban disparities. These complex divisions in Ghana affect everybody and everything that is done in one way or the other, from admission to schools, medical attention, the search for jobs, developmental projects, internal revenue calculation and payment, tax payments, and so on. Some form of affiliation must be paid for everything that is done in Ghana to get better treatment. Price confirmed that in Ghana, people with ethnic perspectives

36 Peter Sarpong. Odd Customs: Stereotypes and Prejudices. (Accra: Sub-Sahara Publishers, 2013), 33-34.

37 Sarpong. Odd Customs, 35-36.

38 Herbert W. Armstrong, Ghana Religions. Index Mundi 2019. https://www.indexmundi.com/ghana/religions.html Accessed on $13 / 5 / 2020$.

39 Cosmos E. Sarbah, Christian-Muslim Dialogue in Ghana: Competition or Co-operation? https://ghanjol.org.gh/index.php/erats/issue/download/18/ERATS_27-71-1\%281\%29-17. Accessed 24 January 2020.53.

40 Rijk Van Dijk 'Contesting Silence: The Ban on Drumming and the Musical Politics and Pentecostalism in Ghana' Ghana Studies, 4. (2001): 31-64.

${ }^{41}$ Paa Kwasi Forson. "Ban on Drumming, Book Long and Matters Arising” Feature Article in Modern Ghana, 16/05/2012. www.modernghana.com/news/395808/ban-on-druming-book-long-and-matters-arising-html. 
expect both favouritism from people in their ethnic or tribal groups and discrimination from other ethnic or tribal groups in the civil service. He continued to state that an appreciable number of Ghanaians expect ethnic discrimination from non-tribal members in the civil service. ${ }^{42}$

In short, there are various forms of barriers in Ghana that breed different levels of religious, and ethnic discrimination that pose a threat to security and integral development that need attention.

\section{THIRD POLE OF THE WORK: APPROPRIATION Introduction}

This section attempts a dialogue between the issues that came out of the reading process and the Ghanaian context so that while the text critiques the context, the context will also enlarge the understanding of the text.

\section{The Text and Ethnicity in Ghana}

The text raises the issue of Jewish priority in the missionary activities of Jesus in accordance with the covenant promise to Abraham in Gen. 12:1-3. This is an indication that as a Jew, Jesus shared certain Jewish sentiments, traditions, scriptures, cultures and language. The Jews were very proud that they were the chosen, the favoured of God and the observance of the commandment and other Jewish practices made them pure and different from all other nations. By this, the text establishes the importance of ethnicity as it gives the identity, defines the history and enhances the dignity of the individual persons and community as a whole. This creates a sense of belonging and cohesion needed for the development of society. However, as an ethnic group, the Jewish society looked down on all other nations as unclean, called them names (dogs), and placed them outside the confines of salvation. This manifests the negative dimension of ethnicity. The text establishes that the presence of Jesus marks a new age which God had prepared for all other nations to share in the blessings of Abraham and to become new members of the covenant community. This new age is not based on physical affiliation but on faith in God. Thus, Jesus lifted human relations to a new theological level and broke ethnic barriers. This is a covenant renewal moment by which people from different ethnic groups are accepted into God's family. Jesus is the covenant giver, the mediator and the enforcer. The woman is the covenant receiver together with her household. There is a transformation for herself and her household on one part and the expansion of the scope of Jesus's ministry on the other part.

Similarly, many Ghanaians did not choose to belong to a particular ethnic group. They were born into it and they share certain history, traditions, language, culture and pride. It may be natural if members of such ethnic groups like and support each other. They may have perceived other Ghanaians as hostile, simply because they belong to historically enemy tribes. Consequently, some Ghanaians expected better treatment from members of their ethnic groups and discrimination from members of other groups. The text invites readers to transcend ethnic barriers and respond to the needs of those who are different. No one deserves to be called "names" as all are one in Christ.

\section{The Text and Religion in Ghana}

The text again discusses an encounter between two persons with different religious persuasions: Jesus and the woman, Judaism and paganism respectively. The text confirms the initial prejudices that are manifested in the face of the Jewish religion as against other religions (Acts 10:1-43). This shows how people from powerful/ dominant religions may refuse to minister to those considered outsiders or minorities. The woman on the other hand reverenced Jesus as Lord, and humbly prostrated herself before him in adoration because she needed his services. There is a power play in the story between the weak and the strong, majority and minority, male and female, and powerful and less powerful that must be overcome by complimenting one another.

The text also confirms that dialogue is the key to breaking religious barriers. It is important to listen to one another with openness, respect and tolerance. Interfaith dialogue is essential in eliminating religious animosities.

Ghanaians belong to different religious groups and denominations; yet, they all serve one God and have entered into various degrees of covenants with him. The text reveals that different religions may easily

${ }^{42}$ Price. "Patterns of Ethnicity in Ghana". 
serve one another for common good. It is important to dialogue in order to come to the realization that all Ghanaians are partners who must complement each other in serving God and one another and not opponents who must outwit one another. Many religions believe in the existence of a God, and those who do not, believe in their conscience concerning what is good and what is not. These must be respected in a mutual and complementary way for the benefit of all. There is no need to take an entrenched position to over-emphasise the importance of one tribe or religion as against others whether in minority or majority groups.

\section{CONCLUSION}

The episode between Jesus and the Syrophoenician woman is a covenant renewal discourse to break barriers. The renewal aimed to include other groups (nations/states and/or religious groups) into the covenant family of God based on faith in Jesus Christ. The effects of the renewal are the transformation of the woman and her household on one side and the expansion of the missionary scope of Jesus on another. This is in fulfilment to the covenant promise to Abraham and this theology is also Pauline. The episode affirms that ethnicity is good in itself, it creates a good social and religious environment for an interpersonal relationship that may be transformative. Yet, no single group should be used as a standard for all other groups as this may breed superiority and inferiority complex. The text teaches how to break unproductive ethnic and religious barriers in order to make the family of God all-inclusive. There is no need for name-calling and discrimination to denigrate one another. Mutual respect and trust promote interpersonal relations that may be transformative.

\section{RECOMMENDATIONS}

Dialogue is essential to break barriers and mutual respect in dialogue is important in the face of diversities of opinions and perspectives. The text exhorts all traditional leaders, teachers, union leaders, politicians, pastors and all stakeholders to welcome people from different groups as partners. The majority groups should accommodate and appreciate minority groups and vice versa for the smooth running of society and the common good of all.

\section{ABOUT AUTHOR}

Alice Matilda Nsiah (Rev. Sr. Dr.) is a senior lecturer at the Department of Religion and Human Values, University of Cape Coast, Ghana. Her research is centered on some controversial biblical passages on women in the New Testament. She reads these passages as covenant discourses, focusing more on some of the innovations that Jesus added to the life of women in the gospels. She enjoys reading biblical text with Ricoeurian theories,sometimes combining this with some African hermeneutic theories.

\section{BIBLIOGRAPHY}

Alt, Christopher.The Dynamic of Humility and Wisdom: The Syrophoenician Woman and Jesus in Mark 7:24-30. Lumen Et Vita, (2012) 2(1). https://doi.org/10.6017/iv.v2i1.1901

Armstrong, Herbert W. Ghana Religions Index Mundi 2019. https://www.indexmundi.com/ghana/religions.html Retried 13/5/2020

Asante Richard \& E. Gyimah-Boadi. Ethnic Structure, Inequality and Governance of the Public Sector in Ghana. Published by United Nations Research Institute for Social Development (UNRISD) 2004. http://unrisd.org/80256B3C005BCCF9/(httpAuxPages)/8509496C0F316AB1C1256 ED900466964...

Awumbila, Mariama How to Close the North South Gap in Ghana (interview at The 2016 Global Forum on Development. (Reported by Andrew Wheeler (2017) retrieved from https//idear4development.org.

Dijk R.V. Contesting Silence: The Ban on Drumming and the Musical Politics and Pentecostalism in Ghana. Ghana Studies, 4. (2001), 31-64.

Donahue, J.R. and Harrington, D.J. The Gospel of Mark. Collegeville, Minnesota: The Liturgical Press, 2002. Gundry, R.H. Mark: A Commentary on His Apology for the Cross. Grand Rapids, Michigan: William B.

Eerdmans Publishing Company, 1993. 
Global Forum on Development. (Reported by Andrew Wheeler (2017) retrieved from https//idear4development.org.

Isajiw, Wsevolod W. Definition and Dimensions of Ethnicity: A Theoretical Framework in Challenges of Measurement on Ethnic World: Science, politics and reality. Proceedings of the Joint Canada-United State Conference on Measurement of Ethnicity April 1992, Statistics Canada and U.S. Bureau of Census, eds. Washington D.C.: Government Printing Office: 407-27, 1993.

Just, Felix. Ethnic / National / Religious Groups in Biblical Times. In Catholic Resources for Bible, Liturgy, Arts and Theology, 2019. Retrieved from https://catholic-resouces.org/Bible/Ethnic_Group.htm

Lane, William L. The Gospel According to Mark: The English Text with Introduction, Exposition, and Notes. Michigan: William B. Eerdmans Publishing Company, 1974.

Pheme Perkins. 'The Gospel of Mark: Introduction, Commentary, and Reflections,' The New Interpreter's Bible Vol. VIII Nashville: Abindon Press, 1995. 673-674.

Price, Robert M. "Patterns of Ethnicity in Ghana: A Research Note," Journal of Modern African Studies, Vol. 11, No. 3 (Sept., 1973), 470-475. Cambridge University Press https://www.jstor.org/stable/159616 Accessed: 20/12/2019: 21:56.

Ricoeur, Paul. Interpretation Theory: Discourse and Surplus of Meaning. Fort Worth, Texas: The Texas Christian University Press, 1976.

Sarbah, Cosmas E. "Christian-Muslim Dialogue in Ghana: Competition or Co-operation." E-Journal of Religious And Theological Studies, 3 no.1 (2017).

Sarpong, Peter. Ghana in Retrospect: Some Aspects of Ghanaian Culture. Tema: Ghana Publishing Corporation, 1974.

. Odd Customs: Stereotypes and Prejudices. Accra: Sub-Sahara publishers, 2013.

West, Gerald. Biblical Hermeneutics in Africa. In A Reader in African Theology. John A. Parratt (Ed.). London: SPCK 1987.

2010 Population \& Housing Census: Summary of Final Report. Accra: Ghana Statistical Service,2012. https://www.statsghana.gov.gh/gssmain/storage/img/marqueeupdater/Census2010_Summary_ report_of_final_results. Retrieved 18/8/2019. 